\title{
Erratum to: Work disability and productivity loss in patients with inflammatory bowel diseases in Hungary in the era of biologics
}

Michael D. Mandel • Anita Bálint • Barbara D. Lovász · László Gulácsi • Bálint Strbák · Petra A. Golovics · Klaudia Farkas · Zsuzsanna Kürti • Blanka K. Szilágyi · Anna Mohás · Tamás Molnár · Péter L. Lakatos

Published online: 29 May 2014

(c) Springer-Verlag Berlin Heidelberg 2014

\section{Erratum to: Eur J Health Econ}

\section{DOI 10.1007/s10198-014-0603-7}

In the original publication, the name of the first author has been incorrectly published. The corrected name is given in this erratum.

The online version of the original article can be found under doi:10.1007/s10198-014-0603-7.

M. D. Mandel · B. D. Lovász · P. A. Golovics · Z. Kürti ·

B. K. Szilágyi · A. Mohás · P. L. Lakatos ( $\square)$

1st Department of Medicine, Semmelweis University, Korányi

Sándor utca 2/A, 1083 Budapest, Hungary

e-mail: lakatos.peter_laszlo@med.semmelweis-univ.hu
A. Bálint · K. Farkas · T. Molnár
1st Department of Medicine, University of Szeged, Korányi
fasor 8-10, 6720 Szeged, Hungary
L. Gulácsi · B. Strbák
Department of Health Economics, Corvinus University
of Budapest, Fővám tér 8, 1093 Budapest, Hungary 